\title{
3-D seismic exploration across the deep geothermal research platform Groß Schönebeck north of Berlin/Germany
}

\author{
Charlotte M. Krawczyk ${ }^{1,2^{*}}$, Manfred Stiller ${ }^{1}$, Klaus Bauer ${ }^{1}$, Ben Norden ${ }^{1}$, Jan Henninges ${ }^{1}$, Alexandra Ivanova ${ }^{1}$ \\ and Ernst Huenges ${ }^{1,2}$
}

\author{
${ }^{*}$ Correspondence: \\ lotte@gfz-potsdam.de \\ ${ }^{1}$ GFZ German Research \\ Centre for Geosciences, \\ Telegrafenberg, \\ 14473 Potsdam, Germany \\ Full list of author information \\ is available at the end of the \\ article
}

Alexandra Ivanova is

formerly affiliated with GFZ

German Research Centre for

Geosciences, Telegrafenberg,

14473 Potsdam, Germany

\begin{abstract}
The North German Basin is one of the three major type localities in Germany for deep geothermal energy. Here, the pore space is the dominant parameter, in contrast to fractures (Rhine Graben) and karst (Molasse Basin). To further develop the geothermal research platform Groß Schönebeck located in the Northeast German Basin, a subset of the North German Basin, we investigated the geological structure and the existence of possible fault systems in the subsurface. For this purpose, we carried out a high-resolution 3-D reflection seismic survey at the location to overcome methodical restrictions of the few 2-D seismic profiles that cross the area of interest, such as spatial focusing effects and fault imaging. The survey area extends $8 \mathrm{~km} \times 8 \mathrm{~km}$ at the surface and focusses down to reservoir depths at $4 \mathrm{~km}$. With four vibrators as source (12-96 Hz sweep, $12 \mathrm{~s}$ duration), we used a source line spacing of $700 \mathrm{~m}$ and a receiver line spacing of $400 \mathrm{~m}$ with both $50 \mathrm{~m}$ source and geophone spacing. Data processing encompassed CRS (Common Reflection Surface) stacking, post-stack time migration and depth conversion. We observed a smooth doming of the Zechstein salt from 0.6 to $1 \mathrm{~km}$ thickness above the continuous top of the Rotliegend Group at around $4 \mathrm{~km}$ depth, and the Mesozoic horizons above appear as mainly continuous reflection surfaces with gentle undulations and occasional normal faulting. We highly resolved the supra-salt sequences in the study area for the first time, which allowed us image an almost complete suite of reflectors mapped in other parts of the Northeast German Basin. However, less resolved, lower frequency images are encountered deeper than $\sim 4 \mathrm{~km}$. Two important factors for further field development are that we do not observe an apparent influence of crustal-scale faults, which were expected from former conceptual models for the region, and that at the current status of work, the reservoir does not show a fracture-dominated character.
\end{abstract}

Keywords: Geothermal exploration, North German Basin, Reservoir characterization

\section{Background}

The extraction of hydrogeothermic energy from deep wells is deemed of great relevance in the energy transition in Germany, and therefore, tested and developed in scientific case studies. The largest cost factor for geothermal projects is deep drilling, and 3-D seismic surveys are often used in advance of drilling exploration wells for optimization of drill paths.

(c) The Author(s) 2019. This article is distributed under the terms of the Creative Commons Attribution 4.0 International License (http://creativecommons.org/licenses/by/4.0/), which permits unrestricted use, distribution, and reproduction in any medium, provided you give appropriate credit to the original author(s) and the source, provide a link to the Creative Commons license, and indicate if changes were made. 
In the research project, RissDom-A (RissDominierte Erschließung in German: fracture-dominated exploitation), we examine the use of deep geothermal resources in the North German Basin (NGB) by 3-D seismic structural exploration at the geothermal research platform in Groß Schönebeck, hosted by the German Research Centre for Geosciences (GFZ) Potsdam (Reinsch et al. 2015). Like the NGB, sedimentary basins are found worldwide consisting of different, superimposed sedimentary layers that may contain large resources of deep geothermal waters, e.g. in Greece (Mendrinos et al. 2010), the Polish Trough (Pussak et al. 2014), Nevada (Siler et al. 2016), and Australia (Ricard et al. 2016).

In Germany, sedimentary environments were imaged recently with 3-D seismic surveys in the Molasse Basin (Lüschen et al. 2014) and the Rhine Graben (Buness et al. 2014). Together with the study presented here, the three major geothermal target areas in Germany are now covered by academic 3-D seismic surveys imaged nominally with 15-25 m bin size. The survey in the Rhine Graben has an extent of $5 \times 5 \mathrm{~km}$ and reveals small-scale faults (Buness et al. 2014). The Molasse Basin is covered by several surveys targeting the Malm Formation at approximately $3 \mathrm{~km}$ depth. Faults in the Tertiary sequences immediately above and in the vicinity of existing wells were imaged with partly $15 \mathrm{~m}$ bin size in the Unterhachingen survey of $4 \times 5 \mathrm{~km}$ size, revealing karstic processes and possible sinkholes (Lüschen et al. 2014).

Hard rock environments were recently surveyed with 3-D seismic for geothermal use in, for instance, the Larderello-Travale region in Tuscany, Italy (Aleardi et al. 2015) and Schneeberg in Saxony, Germany (Hloušek et al. 2015). Here, a late-Variscan granitic pluton within the Erzgebirge area may serve in the future as petrothermal reservoir. The 3-D seismic survey had a size of $10 \times 10 \mathrm{~km}$ and covered some prominent large-scale fault structures (penetrating from surface to several $\mathrm{km}$ depth) of which the Roter Kamm fault system and its conjugates characterize the granitic pluton most prominently (Hloušek et al. 2015). Since there is no well drilled yet to correlate seismically determined fracturing, upscaling is not possible here. In contrast, well and seismic data could be well correlated in the Tuscany granites (Aleardi et al. 2015). Reflection amplitude versus source to receiver azimuth analyses of the seismic data $(5 \times 5 \mathrm{~km}$ surface extent, explosive sources) reveal intense fracturing in the contact zone between 2 and $3 \mathrm{~km}$ depth, accompanied by significant velocity and density contrasts causing highreflection amplitudes.

Since the site under investigation here serves as a reference for the development of geothermal technologies, the seismic measurements in Groß Schönebeck aim at providing a detailed image of the target region in the porous sedimentary and volcanic Rotliegend Group of the Northeast German Basin (NEGB).

Project RissDom-A targets at the fracture-dominated development of a deep geothermal reservoir for energy generation in the North German Basin, based on seismic exploration, concept and well planning at the Groß Schönebeck site. It addresses questions like: (1) location of fault zones and other structural elements, (2) characterization of the reservoir and hydraulic induced fracture systems under consideration of different stress conditions, and (3) selection of suitable completion materials for a geothermal well.

Following, we report about the 3-D seismic exploration survey, with emphasis on layout, accomplishment, and first depth model interpretation. 


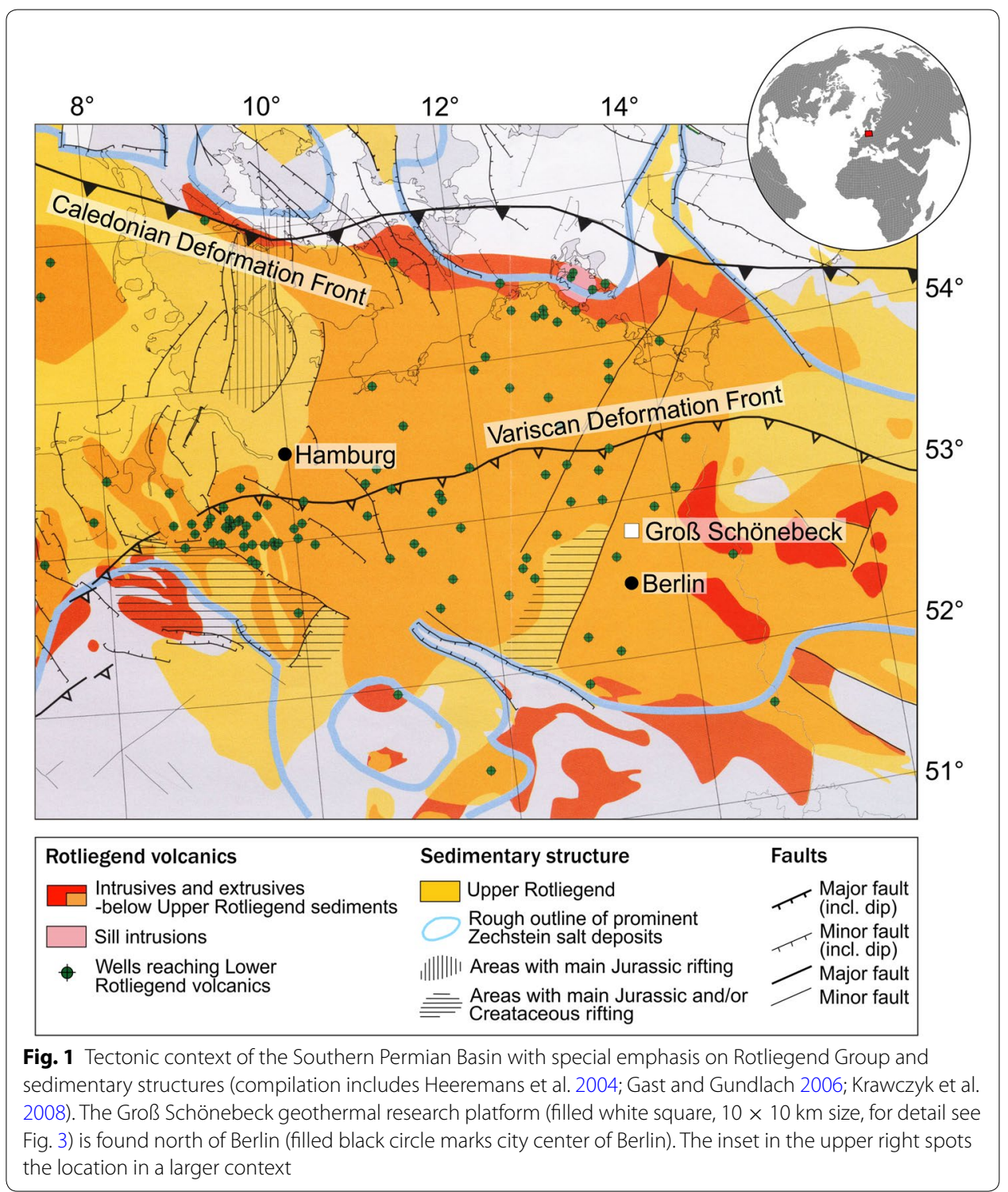

\section{Site Groß Schönebeck}

The investigation area Groß Schönebeck is located $\sim 50 \mathrm{~km}$ north of Berlin, in the biosphere reserve Schorfheide and on the southern edge of the Northeast German Basin (see Krawczyk et al. 2008, and references therein; Krawczyk and Schulze 2015; Fig. 1). Two research wells have reached horizons between 3.9 and $4.4 \mathrm{~km}$ depth, where temperatures of $\sim 150{ }^{\circ} \mathrm{C}$ were found (Zimmermann et al. 2011). The boreholes intersected the Mesozoic basin infill and the Zechstein salt, finally reaching into the Carboniferous (Fig. 2).

The expansion of the site began in 2001, when a dry natural gas exploration well (E GrSk 3/90) was re-opened, and the GFZ successively solicited research projects to build up an in situ geothermal laboratory. Under this framework, the research on geothermal technology was understood as an integrated approach, including the interaction of exploration, drilling, reservoir engineering, completion, operation of the geothermal 


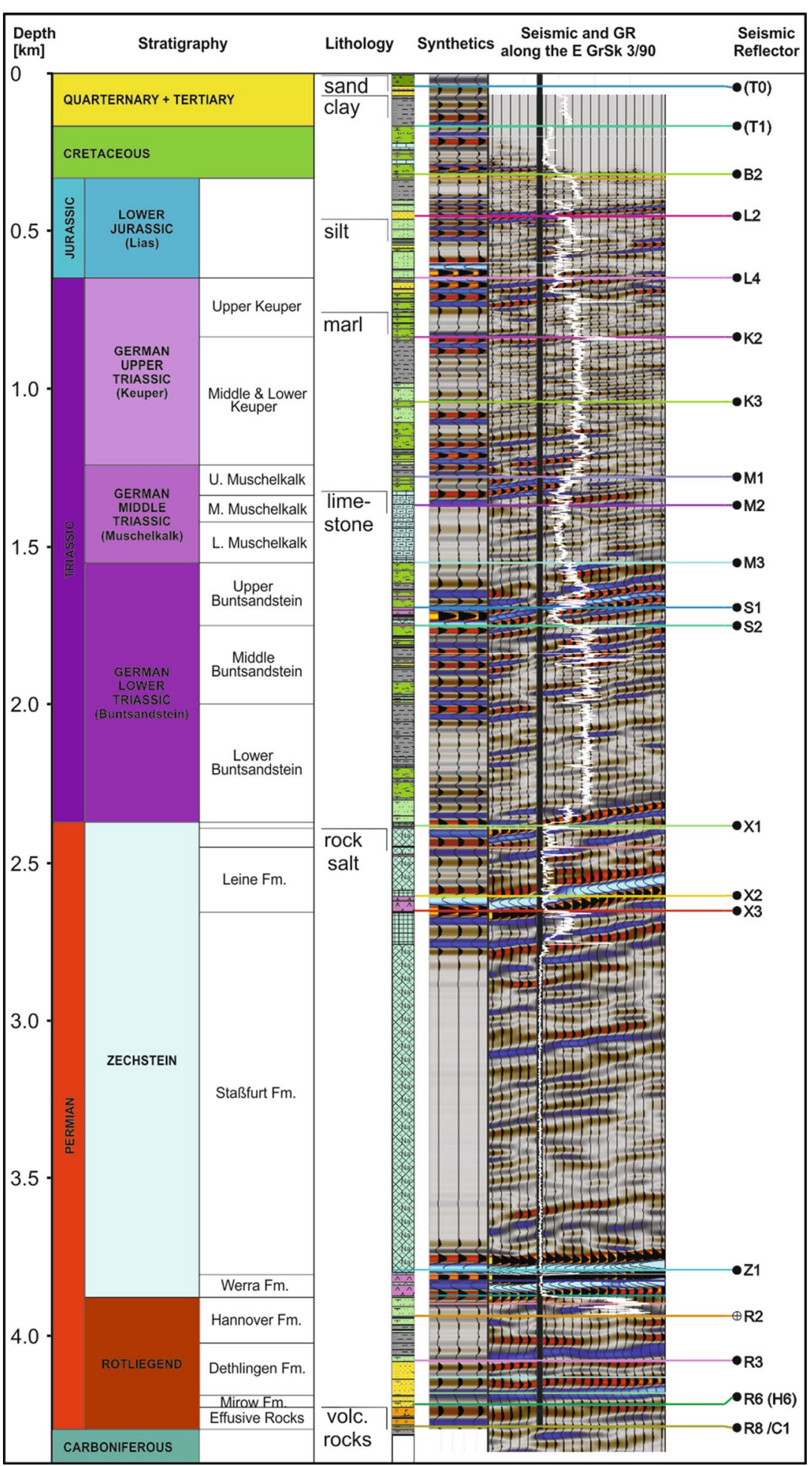

Fig. 2 Stratigraphy of borehole GrSk 3/90 (supplemented and revised from Moeck et al. 2009). Located in the centre of the $8 \times 8 \mathrm{~km}$ survey area, it yields the lithology of the region. According to the Southern Permian Basin nomenclature (after Reinhardt 1993), we define standard reflector names that will be further used for labeling in subsequent figures. These reflectors are verified together with the borehole Gamma log (white curve overlay, $0-150 \mathrm{API}$ range) and synthetic seismic traces 
loop, and finally the conversion of heat into energy usage. Only six 2-D seismic profiles, obtained between 1971 and 1990, existed in the area and were summarized in an interpolated 3-D geological model (Moeck et al. 2009). In all six sections, the top of Lower Permian volcanic rock (referred to as reflector H6), the top of the Elbe Basis sandstone (R2) and the top of the silt-clay successions in the Hannover formation (R1) were detected, while Top Carboniferous was rarely seen. The subsurface of the Schorfheide biosphere reserve is characterized by a Mesozoic antiform, which in turn sits on a salt spine. Here, the Zechstein salt presents thickness of approximately $1 \mathrm{~km}$ and decouples sub- and supra-salt layers (Krawczyk and Schulze 2015; Fig. 2). The Rotliegend Group seems segmented by probable structures predominantly NW-SE oriented, few of which were active even after the Permian (Fig. 1).

As part of the EU-funded project I-GET, geophysical surveys were carried out in the area (Huenges and Bruhn 2009), with a combination of seismic and magnetotelluric measurements to determine the size of the potential reservoir. The tomographic interpretation down to a depth of $6 \mathrm{~km}$ assigns high-resolution P-wave velocities to the sediment sequences of the Cenozoic to pre-Permian, ranging between 1.8 and $5.5 \mathrm{~km} / \mathrm{s}$, which provide very detailed information down to the salt at $4 \mathrm{~km}$ depth (Bauer et al. 2010). A sub-vertical zone of reduced velocity below the salt was defined as interference in the pre-Permian, even though this zone has not been structurally shown so far. Changes in the velocity gradient of $1-2 \mathrm{~km} / \mathrm{s} / \mathrm{km}$ above and $0-0.5 \mathrm{~km} / \mathrm{s} / \mathrm{km}$ below, were observed at a depth of $2-3 \mathrm{~km}$. These changes were interpreted as a transition from mechanical to chemical compaction (Bauer et al. 2010). A joint statistical evaluation of the seismic with magnetotelluric data (Muñoz et al. 2010) was used to classify the sediments. It indicated that high velocities, of $4.9-5.2 \mathrm{~km} / \mathrm{s}$, occur together with low resistivity values in areas of thin evaporitic layers.

The second well (Gt GrSk 4/05) was drilled in 2006. Together with the first one, it was connected to a thermal circuit aboveground. An extensive series of experiments were carried out with this doublet to examine the suitability of this location as a type example for geothermal power generation in the Northeast German Basin (Reinsch et al. 2015; Regenspurg et al. 2015; Blöcher et al. 2016). These experiments led us to the conclusion that a geometrically different exploitation setup was needed, presumably a modified drill path. For this purpose, we started a more detailed characterisation of the target region, including the 3-D seismic survey presented here.

\section{Methods: 3-D seismic field surveying}

Reflection seismic is a common method of applied geophysics to map the Earth's crust. We chose vibroseismic for deep geothermal exploration because it is the least destructive seismic exploration method. In this method, periodic sound waves are generated and radiated by hydraulic vibrator units mounted on lorries. There are numerous references for both general and detailed descriptions of seismic exploration approaches (see Keary and Brooks 1991; Sheriff and Geldart 1995; Yilmaz 2001), as well as specifically related to geothermal energy (e.g., von Hartmann et al. 2015; Kana et al. 2015). Following we discuss our workflow optimized for the detailed exploration of the reservoir, complemented with information about timelines that this kind of survey demands. 
Table 1 Acquisition parameters of the 3-D seismic survey in Groß Schönebeck

\begin{tabular}{ll}
\hline Survey parameter & Parameter value \\
\hline Survey period & Feb/March 2017 (17 work days) \\
Seismic source (regular) & 4 vibrators M12/606-Hemi 48, each 200 kN \\
Sweep & Linear up, 12-96 Hz, 8 × 12 s, 360 ms taper \\
Source interval & 50 m (48 m linear pattern) \\
Line distance & $700 \mathrm{~m}$ \\
Number vibrator points & 1830 \\
Seismic source (exceptional) & 15 explosive shots (each 1.2 kg charge, 10-15 m deep) \\
Geophone type & Sercel jF-20DX, 12 per group \\
Receiver interval & 50 m (linear pattern, 4.15 m geophone spacing) \\
Line distance & 400 m \\
Number of receivers & 3240 (all active) \\
Instrument & Sercel system 428, v5 \\
Recording & Unstacked, uncorrelated \\
Trace length & $5 \mathrm{~s}$ (correlated) \\
Sampling interval & 2 ms \\
\hline
\end{tabular}

\section{Campaign planning and preparation}

The time for preparing the seismic survey was just over 7 months. In addition to the design of the experiment and in-depth scouting of the investigation area, we executed all necessary formal steps. These consisted of the public tendering of the contractor services to the application/approval of a main operating plan. Due to the sensitivity of the measuring area, nature conservation expertise and the consent of all responsible institutions with public interests (environment, water, forestry, agriculture, monuments, traffic, etc.) were required (see also Stiller et al. 2018).

The company GGL Geophysik Leipzig was commissioned with the planning of the field configurations for the 3-D seismic and the VSP (Vertical Seismic Profiling) measurements. All resulting field parameters are summarized in Table 1. Approximately, 80\% of the survey area is covered predominantly by a right-angled grid network of forest roads, maintained by the state forest organization. Given this geometry, model calculations for planning an optimal measurement configuration revealed theoretical distances of $400 \mathrm{~m}$ for the receiver and $700 \mathrm{~m}$ for the source lines. The point spacing on the lines was chosen to be $50 \mathrm{~m}$ for sources and receivers to avoid spatial aliasing of the existing layer inclinations, and to ensure sufficient vertical and horizontal resolution after data migration. The seismic contractor performing the measurements was DMT GmbH \& Co. KG, Essen, with its subcontractors IPS Celle for permitting (government and private permits, access rights, restrictions) and Celler Brunnenbau $\mathrm{GmbH}$. The latter prepared only 15 points to use explosives instead of vibrators, for swampy sites inaccessible with the lorries.

\section{Accomplishment of the surface seismic survey}

The field work was done during 17 working days in February/March 2017, consisting of high-resolution 3-D reflection seismic measurements across the geothermal research platform Groß Schönebeck. All the theoretical source and receiver points could be completed, with only moderate changes practically no failures, so that the original 


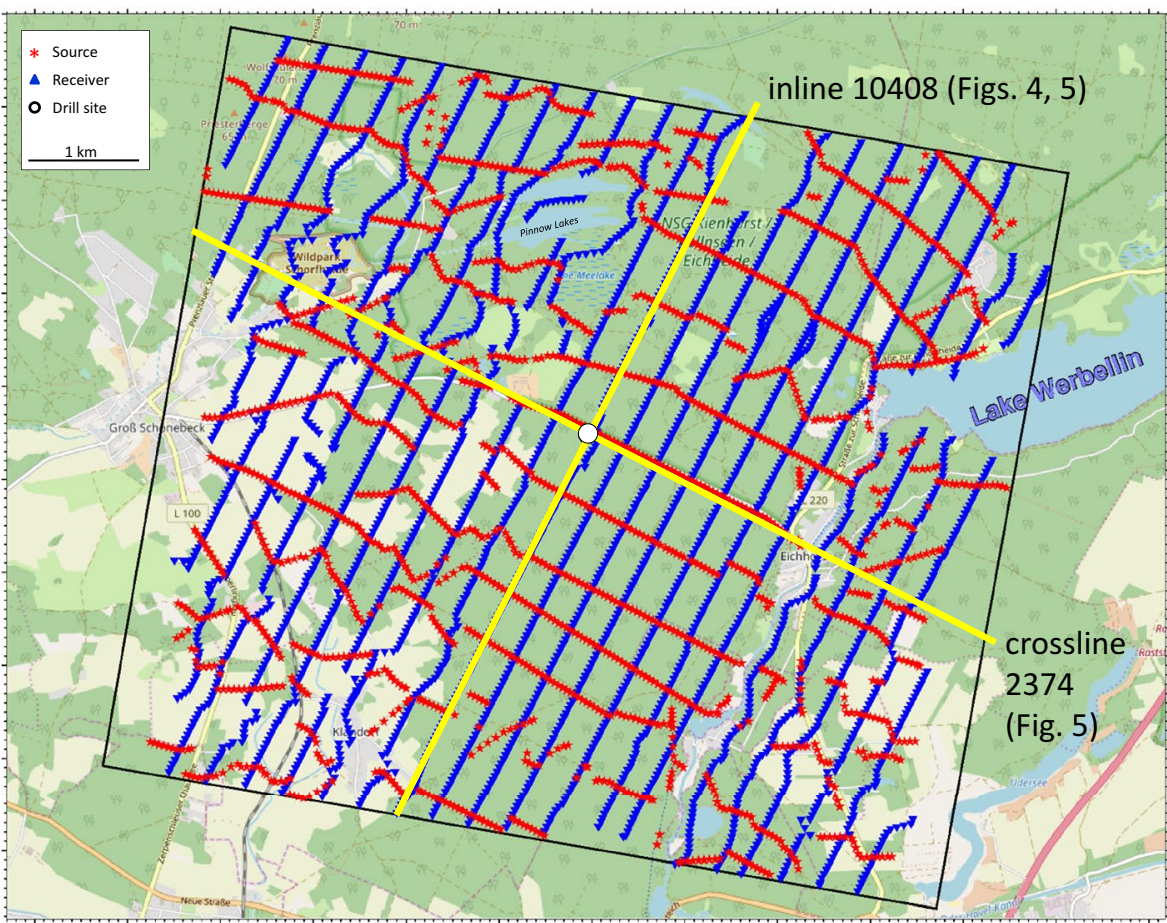

Fig. 3 Actual pattern of the 3-D seismic survey (for location see Fig. 1) with sources (red stars, crosslines) and receivers (blue triangles, inlines) lines. The drilling site (marked with white filled circle at surface location) is traversed by the two sections (yellow lines) shown in Figs. 4 and 5

parallelism of the mutually perpendicular source and receiver lines is still clearly visible in the survey map (Fig. 3).

The location coordinates and ground elevations of all source and receiver points were determined by differential GPS (Global Positioning System), with accuracy up to $25 \mathrm{~cm}$ in height and up to $10 \mathrm{~cm}$ lateral, depending on actual satellite coverage. To map the thickness and velocity of the upper weathering layers, short refraction measurements were carried out once per square kilometer. In combination with the near-offset firstbreak times of the production records, that was enough to take into account the laterally varying delay times of the unconsolidated material.

The seismic source consisted of four simultaneously working vibrators with a peak force of $200 \mathrm{kN}$ each (Table 1). After extensive start-up tests, they emitted eight sweeps (12 s long, 12-96 Hz) at each source location. At locations with very poor signal penetration, we used ten sweeps. Standardized shaking measurements at the closest, potentially endangered objects like houses and technical installations, ensured that the oscillations generated by the vibrators never exceeded the maximum permitted (DIN 4150-3; see Brandenburg State 2005). When the monitoring showed increasing values, the vibrator force was downshifted from high ( $75 \%$ of maximum peak force) to low force ( $40 \%$ of maximum peak force).

Finally, the measuring program contained a total of 1832 source positions and 3240 receiver positions. The amount of materials involved was logistically challenging and quantitatively significant. Connected by over $170 \mathrm{~km}$ of cables in the field, nearly 40,000 
individual geophones were set up to record more than 15,000 individual vibroseismic sweeps. For this purpose, up to 40 vehicles and up to 90 people were working simultaneously in the survey area. In total, it represents more than 2000 person-days and almost 120,000 km driven).

A representative of the company GGD Leipzig was present during the entire active field phase as permanent supervisor. This person checked up the consistent quality of geophone deployment and vibrator performance, evaluated and approved necessary changes at short notice, and communicated back to us. All receiver positions in the measuring area were active throughout the entire campaign, so offsets of up to more than $11 \mathrm{~km}$ were also recorded outside the steep-angle range.

For environmental protection reasons, the local mining authority required an expert in geology and ecology to be present during all activities in the area under consideration, to adapt our operations to the current flora and fauna conditions, in particular, for bird protection at the beginning of nesting and breeding periods. The expert was provided by the company BioLaGu.

Despite the extreme winter weather conditions and the onset of snow and ice melt, the survey was completed in time, before the start of the blocking period for birds' breeding season on March 15. There was only minimal disturbance to humans and nature, so that re-cultivation and compensations were handled quickly and to the satisfaction of the parties involved. The presence of the supervisor and the expert geo-ecologist during all field activities proved very effective and received positive feedback on both acceptance of field measurements and data quality.

The field work was positively accepted by the local population, thanks to a good communication with the public early in the process and a close cooperation with local administration. We developed information sessions in the survey area before, during and after the measurements, and prepared community bulletin boards, citizen contact phone and regular media coverage on the status and course of the campaign, which promoted interest and understanding of the project.

\section{Further experiments}

Parallel to the seismic measurements at surface, a vertical seismic profiling (VSP) experiment was carried out in the $4.3 \mathrm{~km}$ deep research wells E GrSk3/90 and Gt Sk4/05 that constitute the research platform Groß Schönebeck. Accurate time-depth and velocity profiles were determined in order to image structural elements in the vicinity of the boreholes with higher resolution and three-dimensionally. The novel method of distributed acoustic sensing (DAS) used to record the seismic signals is not the focus of this work, instead described in Martuganova et al. (2018) and in more detail in Henninges et al. (2019).

\section{Data processing}

For reasons of quality control, the contractor carried out field processing during the active survey. The first 3-D overview volume (stack only) clearly showed the basic sedimentary structures. Restricting the maximum source-receiver distance to $4200 \mathrm{~m}$, which is the steep-angle range with respect to reservoir depth at $\sim 4 \mathrm{~km}$, the CMP (common 
Table 2 Processing sequence applied to 3-D seismic data volume in Groß Schönebeck

\begin{tabular}{ll}
\hline Workflow segment & Processing tool \\
\hline Field processing & Source-/receiver-/CMP-geometry \\
Main processing & Minimum-phase transformation \\
& Elimination of bad traces \\
& Airwave suppression \\
Data preparation and correction & Static correction (short refraction lines, first-break picks) \\
& Spherical divergence correction \\
& Surface-consistent amplitude correction \\
& Deconvolution (predictive and adaptive) \\
& Residual static correction \\
& Noise-suppression (time-slice analysis) \\
& Common Mid-Point processing: velocity analyses + NMO cor- \\
Stacking-option 1 & rection + stacking \\
Stacking-option 2 & Common Reflection Surface processing: CRS analysis + stacking \\
Migration and depth model building & Post-stack time migration \\
& f-xy deconvolution \\
& Zero-phase transformation \\
& Time-depth conversion \\
\hline
\end{tabular}

mid-point) binning of $25 \mathrm{~m}$ by $25 \mathrm{~m}$ resulted in a nominal 60 -fold background coverage in the survey center.

Approximately, 1.6 terabyte data were analysed during 3-D processing, yielding around 400 vertical inline sections (25 m apart in SSW-NNE direction), 400 vertical crossline sections (25 m apart in WNW-ESE direction), and 2500 horizontal time-slices (vertically $2 \mathrm{~ms}$ apart, respectively 4-12 m). The 3-D seismic main processing (provided by the company DMT Petrologic GmbH \& Co. KG, Hannover) took another 2 months for provision of stacked and migrated data volumes (see processing steps in Table 2). After careful preparation and conditioning of the field data, we followed two methodological approaches. Option 1 was the basic standard processing that consisted of dense NMO (normal move-out) velocity analyses to establish the dynamic traveltime corrections, followed by classical CMP stacking. Option 2 encompassed the creation of CRS (common reflection surface) gathers, which led to an improved signal-to-noise ratio and an overall more coherent imaging continuity. The completion of the initial processing was a poststack time migration moving reflection and diffraction elements to their origin.

The first-processed data cubes show an extraordinarily high data quality, with spatially well-observable sediment structures. The stacked sections of inline 10408 (Fig. 4) reveal strong amplitude and continuous reflectivity events, for instance at 1.2, 1.5, 1.6, and $2.1 \mathrm{~s}$ TWT (two-way traveltime) at the well location (red lines in Fig. 4). The flat lying, strong reflector at $\sim 2.1 \mathrm{~s}$ TWT depth marks the top reservoir level at $4 \mathrm{~km}$ depth. All these features are strong and robust in both stacks, based on CMP (Fig. 4a) and CRS (Fig. 4b) processing, respectively. By further comparing the results of both schemes, pronounced differences were found in the stronger overall continuity of reflectors in the CRS stack (Fig. 4b), which would be expected, and additionally in the uppermost and lowermost parts of the display. Between 0.3 and $1.0 \mathrm{~s}$ TWT, several reflectors of lower amplitude are imaged (Fig. 4b, marked by black arrows), that are barely visible in the CMP stack (Fig. 4a). These are either stronger in amplitude and continuity, or mark reflector packages of higher frequency. 


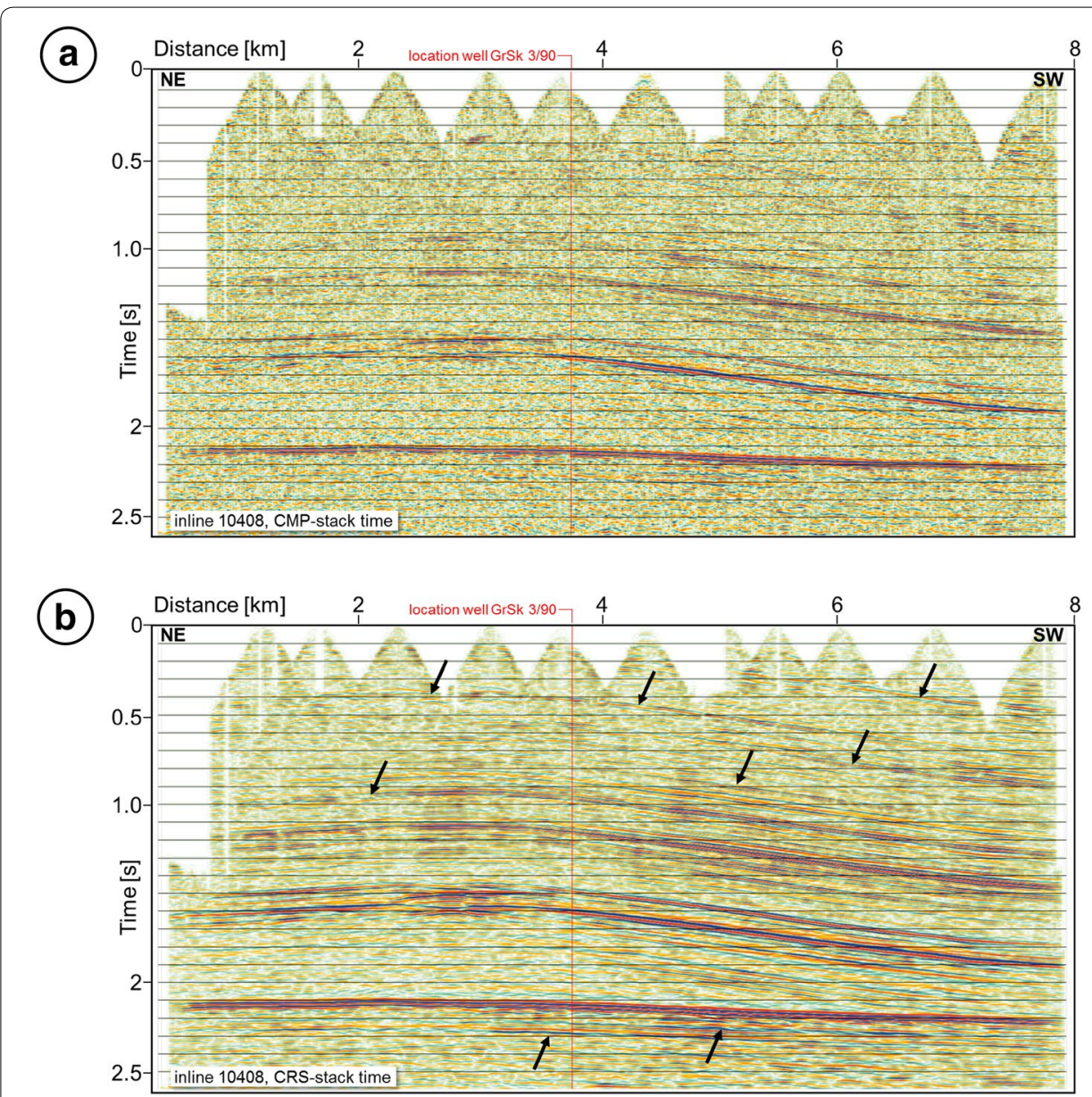

Fig. 4 Stacked sections of inline 10408 (for location see Fig. 3). The high data quality was obvious during field CMP-processing (a) and improved afterwards during CRS-processing $(\mathbf{b})$. The red lines mark the position of research well GrSk 3/90; black arrows point to improvements in $\mathbf{b}$ relative to $\mathbf{a}$

The 3-D seismic data set introduced here was post-stack migrated and converted to depth. With VSP data available, the first breaks of the direct wave were determined for different zero-offset positions. This allowed the calculation of time-depth conversions and interval velocities along the two boreholes, which have then been extrapolated along the structures into the entire 3-D volume. Detailed well tie studies and examinations are available in dedicated manuscripts with respect to seismic modeling (Bauer et al. 2019) and thorough geological interpretation (Norden et al. in revision).

\section{Results and discussion}

Of the many hundreds of possible sections through the migrated 3-D data volume, we extracted those inline and crossline traversing the surface locations of the existing boreholes (see Fig. 3 for locations). The correlation of drilled stratigraphy and lithology with the new 3-D seismic data set allows us to interpret a large number of seismic reflectors with confidence that we introduce for the area under investigation (Fig. 2). Borehole gamma has a smooth signal in the rock salt (Fig. 2, 2.6-3.8 km depth), and its transitions to anhydrite are marked by pronounced peaks, especially seismic reflectors X3 and Z1. 


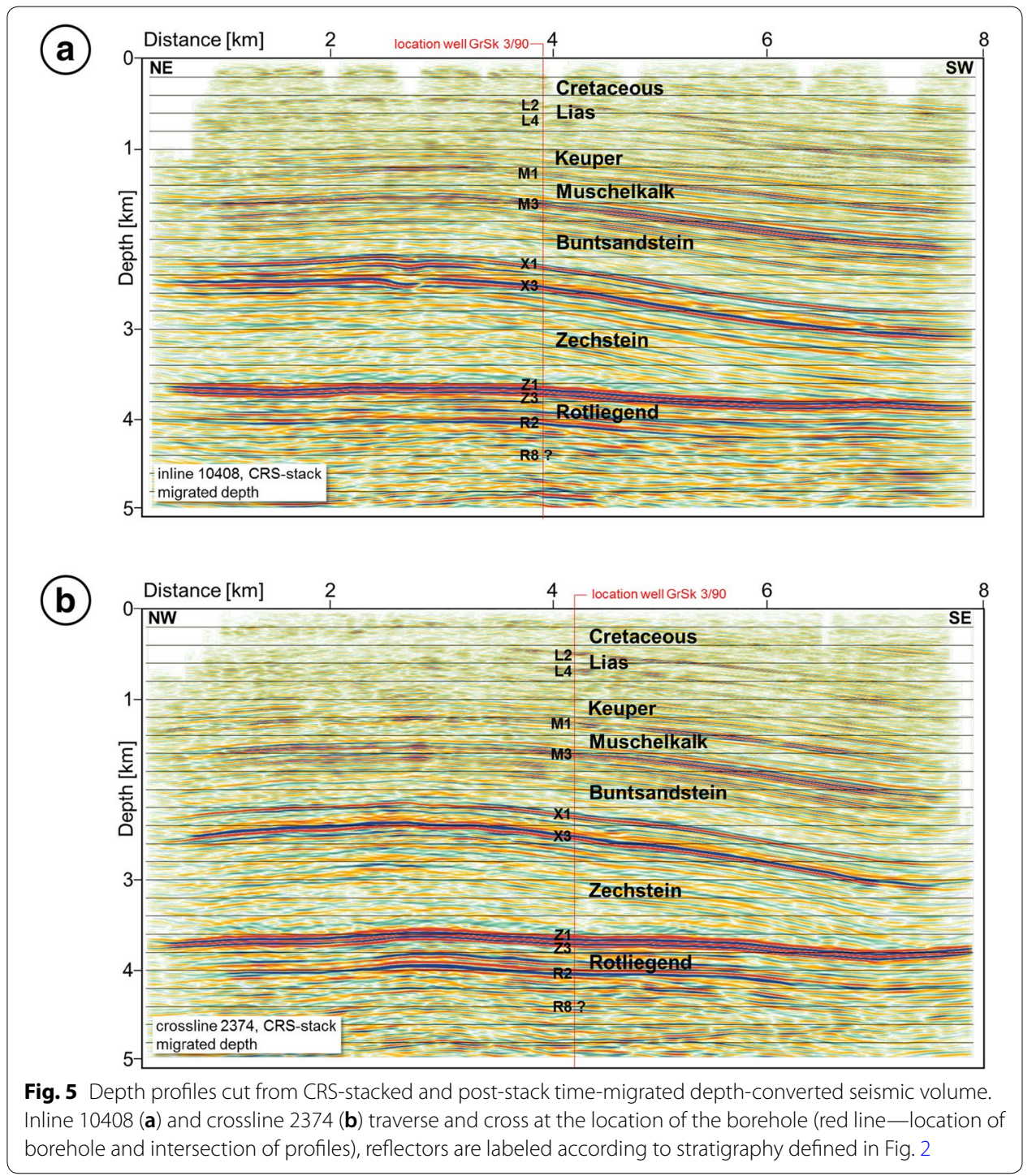

This is also observed in the seismic traces and synthetics next to the borehole (Fig. 2, right half of the panel). The Mesozoic basin infill above Zechstein follows the salt anticline and suites of corresponding lithological reflectors are well recognized in seismic traces and borehole synthetics for Triassic and Jurassic. The reservoir area around $4 \mathrm{~km}$ depth is characterized by high gamma values (Fig. 2, 100-150 API) in the Hannover Formation, and lower values in the gamma log for the Dethlingen sandstones (Fig. 2, 75-100 API) overlying the Rotliegend volcanic rocks.

The subsurface is generally characterized by a wide anticlinal structure of the Zechstein salt (Fig. 5), conformably overlain by the Mesozoic infill of the NE German Basin. Signal strength fades out in the uppermost kilometers below the surface, including some gaps due to missing acquisition coverage at surface (e.g., Fig. 5a around profile $\mathrm{km} 7$, and Fig. $5 \mathrm{~b}$ close to profile $\mathrm{km} 6.3$ ). The advantages of the CRS method (Mann et al. 1999) are particularly relevant in applications for geothermal energy exploration when only few well-covered data sets are available (c.f., Buness 
et al. 2014; Pussak et al. 2014). For hydrocarbon exploration, a 120-fold coverage of each subsurface element is common in modern 3-D seismic surveys, while in geothermal exploration most surveys often reach only half of this coverage. Since this also holds for the 3-D data gathered here (compare Fig. 4a, b), we also decided to continue with the CRS-stacked data for migration and first interpretation.

The various stratigraphic horizons can be traced with high continuity in the migrated depth sections and show a consistent pattern in both inline and crossline directions throughout the entire volume (Fig. 5). The strongest reflector is the double amplitude top Rotliegend (Z3), overlain by rather transparent salt. Both features can be traced with this typical appearance across the entire Southern Permian Basin between England and Poland (see review in Krawczyk et al. 2008, and references therein). Top Zechstein is marked by bright reflectors (X1-X3), and all overlying sequences are characterized by a finer layer structure and higher frequency signal (e.g., Fig. 5a, especially between profile $\mathrm{km} \mathrm{4-6).} \mathrm{Slight} \mathrm{undulations} \mathrm{or} \mathrm{marks} \mathrm{in} \mathrm{the}$ uppermost Zechstein (e.g., Fig. 5a, profile km 3.2, 2.2-2.6 km depth; reflectors X1, X3) are observed. Such structures must be further evaluated individually, because their size is close to the resolution limit. This is also crucial for the Rotliegend Group and below, where reservoir properties, such as pathways along faults, will immediately influence its performance during future use.

These characteristics are also evident in the depth slices cut from the volume at 2.4 and $3.98 \mathrm{~km}$ depth (Fig. 6), emphasizing shallowest Zechstein Group and intermediate Rotliegend Group depths (reflector R2 at well location). In the slice corresponding to the Zechstein depth, the elongated apex of the salt anticline governs the northern half of the area (Fig. 6a), while Buntsandstein deposits are nicely recognizable with many dipping events at its southeastern flank, and to a lesser degree at the northernmost rim of the volume. The Rotliegend depth slice at around $4 \mathrm{~km}$ depth (Fig. 6b) has a distinctly unperturbed appearance and features a rather flat structural character at reservoir level. However, the position of the available wells was advantageous for penetrating the sandstones in a broad zone (Fig. 6b).

With respect to geothermal energy exploration, the focus of this study concentrates on two aspects. First, the sediments above the salt structure were examined to take into account the local depositional conditions and derive the kinematic conditions in this supra-salinar zone for the optimal planning of possible future drilling. Second, the horizons in the Rotliegend Group and Permo-Carboniferous rocks, located in the sub-salinar zone below the Zechstein, are important for geothermal development.

Particularly dominant are reflectors associated with the Zechstein deposits showing strong acoustic contrasts, e.g., reflector X3, transition from anhydrite to salt rock (Fig. 7). The research area encloses only the southernmost section of the larger salt structure Groß Schönebeck-Joachimsthal-Wolletz, which represents an elongated, pillow-shaped SW-NE oriented salt bulge (salt structure No. 23 in Stackebrandt and Beer 2015). The southward extension of this structure is covered by the surveyed area. This structure reaches largest thickness and highest ascent at approximately $2 \mathrm{~km}$ northwest of the center of Groß Schönebeck locality, in the western border of the survey area. The halokinetic processes that led to the formation of this structure probably comprised several stages. Salt movement and formation of the salt pillow began 

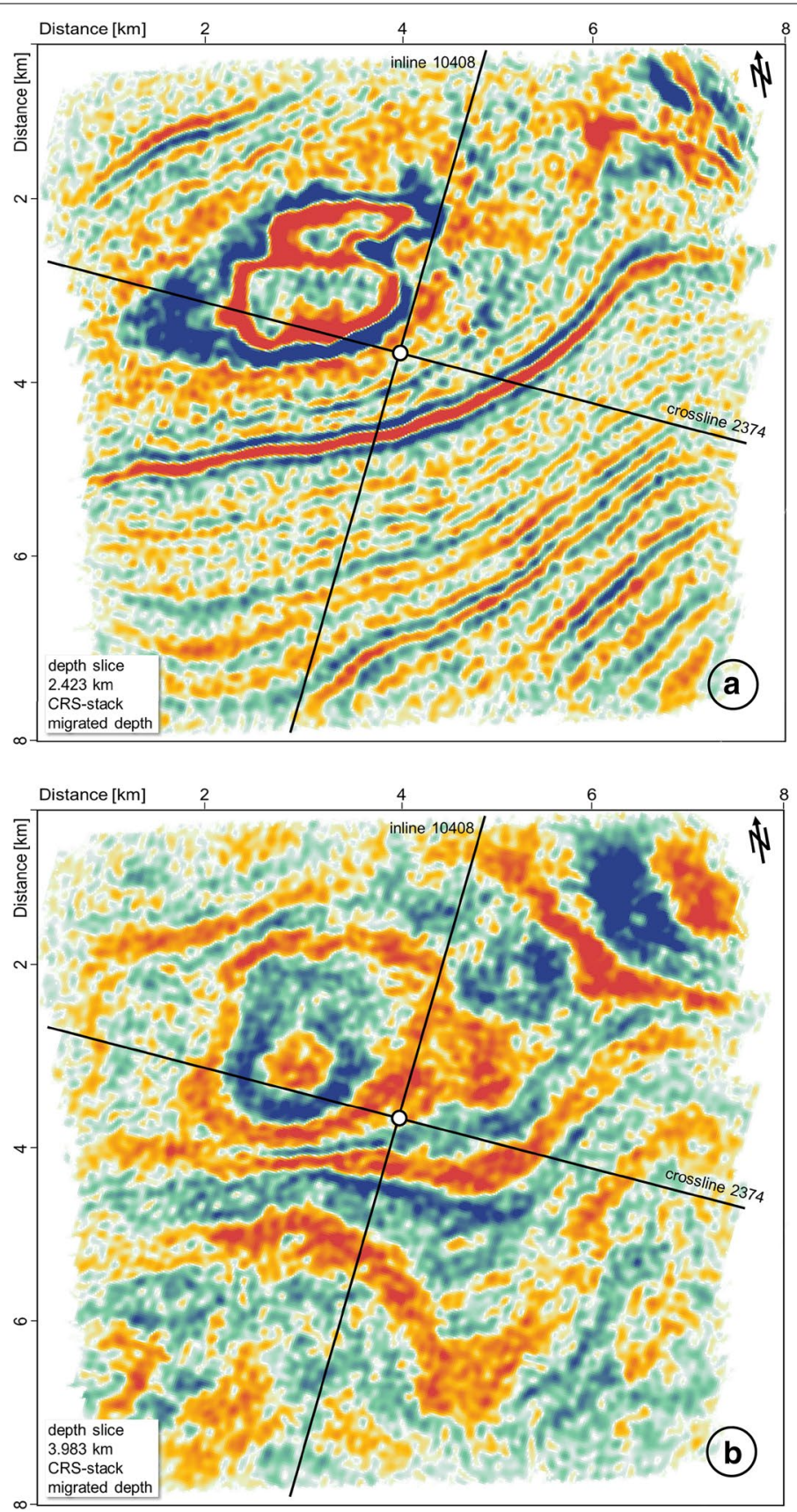

Fig. 6 Depth slices of CRS-stacked and post-stack time-migrated depth-converted seismic volume (black lines - locations of inline and crossline sections shown in Fig. 5; white filled circle-surface location of borehole, c.f. Fig. 3). The displays at $2.423 \mathrm{~km}$ (a) and $3.983 \mathrm{~km}$ (b) depth emphasize top Zechstein (reflector X1) and Rotliegend (reflector R2) structures, respectively (for deviations check vertical sections in Figs. 4 and 5)

in the upper Buntsandstein unit. Progressive migration of salt enabled faulting in the overburden, which is also detectable in the studied area (e.g., Fig. 7, between surface and around $3 \mathrm{~km}$ depth). 


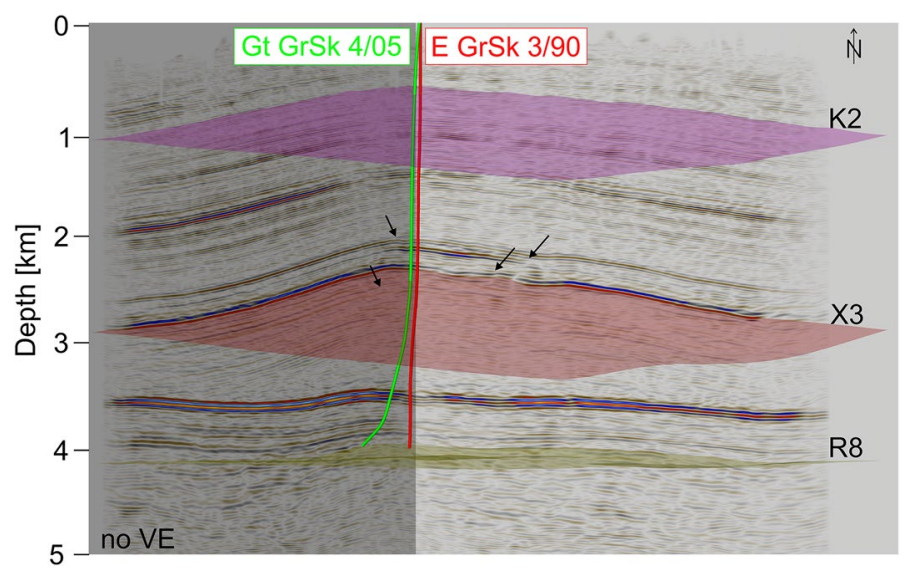

Fig. 7 Composite of the seismic volume (migrated, depth) with selected horizons (view towards north). They exemplify the rather transparent upper Tertiary sediments (K2), the continuous internal Zechstein structure (X3), and the lowermost interpretable Rotliegend horizon (R8). The vertical sections are blended with the drilling paths, used for well tie and synthetics (cf., Fig. 2) to calibrate the reflectors. Several reflectors can be traced with high confidence across the volume, exceeding former interpretations (reflector nomenclature according to Reinhardt 1993)

In the supra-salinar, the western part of the investigation area appears to be more strongly affected by disturbances than the eastern one, where reflectors L2, L4, M1, M3, S1, S2 (Fig. 5) and K2, X3, R8 (Fig. 7) can be mapped with very good confidence. Noticeable here is an annular trench structure, detectable $\sim 1 \mathrm{~km}$ northeast of the drilling location Groß Schönebeck. It might continue westwards as a graben at the top of the salt structure.

A low-velocity zone at GrSk 3/90 was interpreted as the trace of a deep Permian (Rotliegend) to Pre-Permian fault (I-GET profile; Bauer et al. 2010), according to the suggestions of Katzung (1990) and Moeck et al. (2009). For these reasons, we inferred optimal structural conditions for geothermal development from the Rotliegend Group. Since this was not fully met afterwards and productivity decreased (Blöcher et al. 2016), we planned and acquired the funds for a 3-D seismic survey that effectively reveals a different structural setting at depth. Within the Rotliegend Group, below $4 \mathrm{~km}$ depth, structural elements are partially recognizable and laterally not present along the entire length of the volume. Large regional fault structures are not observed, neither grabens as interpreted by Gast and Gundlach (2006) in the NW German Basin. Based on initial results of attribute analyses, we assume that there is no seismic compartmentalization of the observed horizons in the sub-salinar in the vicinity $(<2 \mathrm{~km})$ of the drill holes of the research site Groß Schönebeck.

The rather scarce inventory of fault structures observed here so far may call for further investigations as undertaken in the Molasse Basin, where the internal structure of the Malm platforms and reefs was only revealed by dedicated attribute analyses (von Hartmann et al. 2012; Lüschen et al. 2014). In contrast to typical hummocky crystalline structures (Hloušek et al. 2015) our newly acquired dataset is characterized by well-layered sedimentary successions, which are typical in the Northeast German Basin. The large offsets achieved in our survey (up to $11 \mathrm{~km}$ ) were required for 
a robust imaging at reservoir depths between 4 and $5 \mathrm{kms}$. This is comparable to the layout used in the Schneeberg area. Here, coherency migration imaged distinct faults in an otherwise transparent volume (Hloušek et al. 2015).

Beyond the focus of this paper, large offsets may allow further petrophysical investigations, such as amplitude versus offset analyses, that may yield further indications on fluid content or lithology. In contrast to other fault-dominated geothermal fields like the Salton Sea region, that exhibits a number of active faults imaged by seismic reflection and refraction experiments (McGuire et al. 2015), we have to discard our starting hypothesis, expecting a better imaging of faults interpreted in the conceptual model for the Groß Schönebeck area (see summary in Moeck et al. 2009). Instead, based on the new data, we suggest that some of the faults were either geologically inferred, or assumed from artefacts always contained in 2-D data. Thus, the 3-D seismic study here showed has proven to be superior to 2-D model building alone. But it also proves its use in the planning stage of future drilling concepts and wells.

\section{Summary and conclusion}

The main questions on project RissDom-A for the fracture-dominated development of a deep geothermal reservoir are related to the structure and fault zone identification to characterize the reservoir, as well as the targeting and planning of a deep geothermal well for energy generation in the North German Basin. The 3-D seismic exploration survey we carried out at the Groß Schönebeck site is a well-suited technology to answer those questions.

In comparison to former, profile-based and interpolated interpretations, the new volumetric data gained reveal two major advantages: they correct for spatial effects, often misleading in 2-D data, and have a high-resolution quality. This allowed us a strongly improved identification of structures in the area of interest.

Major structural characteristics are as follows:

- The Zechstein salt is the dominant feature, smoothly doming from 0.6 to $1 \mathrm{~km}$ thickness.

- A continuous top of the Rotliegend Group is found at around $4 \mathrm{~km}$ depth,

- Mesozoic horizons have mainly continuous reflection surfaces with gentle undulations.

- Normal faulting only occurs occasionally in the supra-salt sequences.

- An almost complete suite of reflectors, typical for the NE German Basin, was identified.

As important determinants for further field development at the Groß Schönebeck site, the following factors are identified here the first time:

- No apparent influence of crustal-scale faults, expected from former models, was found.

- There are no indications for free gas.

- No seismic compartmentalization of the observed horizons appears in the sub-salinar zone. 
- The Rotliegend reservoir does not show a fracture-dominated character.

Thereby, some of our former starting hypotheses are no longer valid, and the planning of a third well has to consider these boundary conditions.

Another important conclusion is for the evaluation of a reservoir and the existence of boundaries, it appears mandatory to explore an area of geothermal interest with highresolution surface seismic methods, ideally commented by VSP surveying. This also guides the planning of geothermal wells, with respect to overall exploitation concepts, drill path deviation, and especially stimulation procedures.

\section{Outlook}

Consolidation and improvement of seismic processing, especially at reservoir depths, are envisaged to further corroborate the newly identified structural features and their implications, which are important for later exploration concepts. Furthermore, pattern recognition methods (c.f., Bauer et al. 2012; Pussak et al. 2014) will be used to map seismic facies classes in the geothermal target horizons. In the future, the large offsets of this new data set may also facilitate the application of seismic modeling, for instance using amplitude versus offset (AVO) analyses, to discuss petrophysical reservoir properties. In addition, pre-stack depth migration shall provide the best basis for subsequent geological interpretation and kinematic modeling approaches (c.f., Krawczyk et al. 2015; Ziesch et al. 2017). Updates of our work will finally encompass results from processing scheme applications, like impedance inversion and seismic attribute mapping (see website: RissDom-A 3D seismics 2018). With these measures, we will be able to address the existence of small-scale faults or connectivity within the reservoir, two of the most relevant factors controlling feasibility of geothermal projects.

\footnotetext{
Abbreviations

AVO: amplitude versus offset; CMP: common mid-point; CRS: common reflection surface; DAS: distributed acoustic sensing; GPS: global positioning system; NEGB: Northeast German Basin; NGB: North German Basin; NMO: normal move-out; TWT: two-way traveltime; VSP: vertical seismic profiling.
}

Acknowledgements

We thank the companies that made field work in harsh winter times possible: DMT GmbH \& Co. KG, IPS Informations \& Planungsservice GmbH Celle, GGL Geophysik und Geotechnik Leipzig GmbH, Geophysik GGD Gesellschaft für Geowissenschaftliche Dienste mbH, BioLaGu Biologische Gutachten-Umweltplanung Bleckede, and Schlumberger Limited (VSP). DMT Petrologic GmbH \& Co. KG provided quality control and field processing. Finally we would like to thank two anonymous reviewers who helped improving the manuscript.

\section{Authors' contributions}

CMK and $\mathrm{EH}$ are the PIs of the research project; MS, KB, JH and Al organized and accompanied seismic field work and data processing; BN works on the geological interpretation of the depth volume. All authors wrote the final manuscript. All authors read and approved the final manuscript.

\section{Funding}

The research project RissDom-A is funded by the Federal Ministry for Economic Affairs and Energy, Grant 0324065. The funding supported staff, the design of the study, data collection, as well as analysis and interpretation of data including writing the manuscript.

\section{Availability of data and materials}

The datasets used and/or analysed during the current study are available from the corresponding author on reasonable request. A persistent web link in the GFZ repository will be implemented after embargo dates of the project in 2019.

Competing interests

The authors declare that they have no competing interests.

\section{Author details}

${ }^{1}$ GFZ German Research Centre for Geosciences, Telegrafenberg, 14473 Potsdam, Germany. ${ }^{2}$ Institute for Applied Geosciences, TU Berlin, Ernst-Reuter-Platz 1, 10587 Berlin, Germany. 
Received: 24 November 2018 Accepted: 18 May 2019

Published online: 25 May 2019

\section{References}

Aleardi M, Mazzotti A, Tognarelli A, Ciuffi S, Cassini M. Seismic and well log characterization of fractures for geothermal exploration in hard rocks. Geophys J Int. 2015;203:270-83.

Bauer K, Moeck I, Norden B, Schulze A, Weber M, Wirth H. Tomographic P-wave velocity and vertical velocity gradient structure across the geothermal site Groß Schönebeck (NE German Basin): relationship to lithology, salt tectonics, and thermal regime. J Geophys Res. 2010;115(B08312):1-22. https://doi.org/10.1029/2009JB006895.

Bauer K, Muñoz G, Moeck I. Pattern recognition and lithological interpretation of collocated seismic and magnetotelluric models using self-organizing maps. Geophys J Int. 2012;189(2):984-98. https://doi.org/10.1111/j.1365246X.2012.05402.x.

Bauer K, Norden B, Ivanova A, Stiller M, Krawczyk CM. Wavelet transform-based seismic facies classification and modelling: application to a geothermal target horizon in the NE German Basin. Geophys Prospect. 2019 (in revision).

Blöcher G, Reinsch T, Henninges J, Milsch H, Regenspurg S, Kummerow J, Francke H, Kranz S, Saadat A, Zimmermann G, Huenges E. Hydraulic history and current state of the deep geothermal reservoir Groß Schönebeck. Geothermics. 2016;63:27-43. https://doi.org/10.1016/j.geothermics.2015.07.008.

Brandenburg State. Official Journal No. 23 (in German). 2005. https://www.brandenburg.de/cms/media.php/2162/54_6. pdf. Accessed May 2018.

Buness H, von Hartmann H, Rumpel H-M, Krawczyk CM, Schulz R. Fault imaging in sparsely sampled 3D seismic data using common-reflection-surface processing and attribute analysis-a study in the Upper Rhine Graben. Geophys Prospect. 2014;62(3):443-52. https://doi.org/10.1111/1365-2478.12099.

Gast R, Gundlach T. Permian strike slip and extensional tectonics in Lower Saxony, Germany. Z Dtsch Ges Geowiss. 2006;157(1):41-56.

Heeremans M, Faleide Jl, Larsen BT. Late Carbonifeous-Permian of Central Europe: an introduction to a new regional map. Geol Soc Lond Special Publ. 2004;223:75-88.

Henninges J, Martuganova E, Stiller M, Norden B, Bauer K, Krawczyk CM, Huenges E. Exploration and monitoring with distributed acoustic sensing at the EGS Site Groß Schönebeck. In: Proceedings, European Geothermal Congress. Bruxelles: European Geothermal Energy Council; 2019.

Hloušek F, Hellwig O, Buske S. Three-dimensional focused seismic imaging for geothermal exploration in crystalline rock near Schneeberg, Germany. Geophys Prospect. 2015;63:999-1014.

Huenges E, Bruhn D. I-get integrated geophysical exploration technologies: final conference. Sci Tech Report. GFZ Potsdam; 2009. p. 1-56. https://doi.org/10.2312/gfz.iget2009.

Kana JD, Djongyang N, Raïdandi D, Nouck PN, Dadjé A. A review of geophysical methods for geothermal exploration. Renew Sustain Energy Rev. 2015;44:87-95. https://doi.org/10.1016/j.rser.2014.12.026.

Katzung G. Tektonische Karte der DDR 1:500,000. Berlin: Zentrales Geologisches Institut; 1990.

Keary P, Brooks M. An introduction to geophysical exploration. 2nd ed. Oxford: Blackwell; 1991.

Krawczyk CM, Schulze A. Seismik. In: Geologie von Brandenburg. Stuttgart: Schweizerbart; 2015. p. 508-13.

Krawczyk CM, McCann T, Cocks LRM, England R, McBride J, Wybraniez S. Caledonian tectonics. In: The geology of Central Europe, vol. 1. Geol Soc London; 2008. p. 301-81. ISBNprint: 978-1-86239-245-8.

Krawczyk CM, Henk A, Tanner DC, Trappe H, Ziesch J, Beilecke T, Aruffo CM, Weber B, Lippmann A, Görke U-J, Bilke L, Kolditz O. Seismic and sub-seismic deformation prediction in the context of geological carbon trapping and storage. Adv Technol Earth Sci. 2015;1:97-113. https://doi.org/10.1007/978-3-319-13930-2_5.

Lüschen E, Wolfgram M, Fritzer T, Dussel M, Thomas R, Schulz R. 3D seismic survey explores geothermal targets for reservoir characterization at Unterhaching, Munich, Germany. Geothermics. 2014;50:167-79.

Mann J, Jäger R, Müller T, Höcht G, Hubral P. Common-reflection-surface stack—a real data example. J Appl Geophys. 1999:42:301-18. https://doi.org/10.1016/S0926-9851(99)00042-7.

Martuganova E, Henninges J, Stiller M, Bauer K, Norden B, Krawczyk C, Huenges E. First results of 3D VSP imaging with DAS technology at the geothermal research site Groß Schönebeck/Germany. Geophys Res Abstracts, vol. 20. 2018. https://meetingorganizer.copernicus.org/EGU2018/EGU2018-10093-1.pdf. Accessed 22 May 2019.

McGuire JJ, Lohman RB, Catchings RD, Rymer MJ, Goldman MR. Relationships among seismic velocity, metamorphism, and seismic and aseismic fault slip in the Salton Sea Geothermal Field region. J Geophys Res Solid Earth. 2015;120:2600-15. https://doi.org/10.1002/2014JB011579.

Mendrinos D, Choropanitis I, Polyzou O, Karytsas C. Exploring for geothermal resources in Greece. Geothermics. 2010;39:124-37. https://doi.org/10.1016/j.geothermics.2009.11.002.

Moeck I, Schandelmeier H, Holl HG. The stress regime in a Rotliegend reservoir of the Northeast German Basin. Int J Earth Sci. 2009;98:1643-54. https://doi.org/10.1007/s00531-008-0316-1.

Muñoz G, Bauer K, Moeck I, Schulze A, Ritter O. Exploring the Groß Schönebeck (Germany) geothermal site using a statistical joint interpretation of magnetotelluric and seismic tomography models. Geothermics. 2010;39:35-45. https:// doi.org/10.1016/j.geothermics.2009.12.004.

Norden B, Henninges J, Bauer K, Krawczyk CM. 3-D structural model of the Groß Schönebeck area north of Berlin. Int J Earth Sci (in prep).

Pussak M, Bauer K, Stiller M, Bujakowski W. Improved 3D seismic attribute mapping by CRS stacking instead of NMO stacking: application to a geothermal reservoir in the Polish basin. J Appl Geophys. 2014;103:186-98. https://doi. org/10.1016/j.jappgeo.2014.01.020.

Regenspurg S, Feldbusch E, Byrne J, Deon F, Driba DL, Henninges J, Kappler A, Naumann R, Reinsch T, Schubert C. Mineral precipitation during production of geothermal fluid from a Permian Rotliegend reservoir. Geothermics. 2015;54:122-35 
Reinhardt H-G. Structure of Northeast Germany: regional depth and thickness maps of Permian to Tertiary intervals compiled from seismic reflection data. Spec. Publ. Eur. Assoc. Petroleum Geoscientists, vol. 3; 1993. p. 155-65.

Reinsch T, Blöcher G, Kranz S. Data from the Groß Schönebeck Research Platform 2011-06-01-2013-12-31. Sci Tech Report 15/02:1-71, GFZ Potsdam. 2015. https://doi.org/10.5880/gfz.b103-15021.1.

Ricard LP, Huddlestone-Holmes CR, Pujol M. Reservoir and production engineering challenges for geothermal systems hosted in Australian Sedimentary Basins. Society of Petroleum Engineers 182343-MS:1-14. 2016. https://doi. org/10.2118/182343-ms

RissDom-A 3D seismics. https://www.gfz-potsdam.de/en/section/near-surface-geophysics/projects/rissdom-a-3D-seism ic-experiment-for-geothermal-exploration/. Accessed 16 Apr 2019.

Sheriff R, Geldart L. Exploration seismology, vol. 1. 2nd ed. Cambridge: Cambridge Univ. Press; 1995.

Siler DL, Faulds JE, Mayhew B, McNamara DD. Analysis of the favorability for geothermal fluid flow in 3D: Astor Pass geothermal prospect, Great Basin, northwestern Nevada, USA. Geothermics. 2016;60:1-12. https://doi.org/10.1016/j. geothermics.2015.11.002.

Stackebrandt W, Beer H. Salztektonik Halokinese. In: Geologie von Brandenburg. Stuttgart: Schweizerbart; 2015. p. 472-9.

Stiller M, Krawczyk CM, Bauer K, Henninges J, Norden B, Huenges E, Spalek A. 3D-Seismik am Geothermieforschungsstandort Groß Schönebeck. bbr, 1/2018. 2018. p. 84-91.

von Hartmann H, Buness H, Krawczyk CM, Schulz R. 3-D seismic analysis of a carbonate platform in the Molasse Basinreef distribution and internal separation with seismic attributes. Tectonophysics. 2012;572:16-25. https://doi. org/10.1016/j.tecto.2012.06.033.

von Hartmann H, Beilecke T, Buness H, Musmann P, Schulz R. Seismische Exploration für tiefe Geothermie. Geol Jahrbuch 2015;B104:1-271.

Yilmaz Ö. Seismic data analysis. Tulsa: Society of Exploration Geophysicists; 2001.

Ziesch J, Aruffo CM, Tanner DC, Beilecke T, Dance T, Henk A, Weber B, Tenthorey E, Lippmann A, Krawczyk CM. Geological structure and kinematics of normal faults in the Otway Basin, Australia, based on quantitative analysis of 3-D seismic reflection data. Basin Res. 2017;29:129-48. https://doi.org/10.1111/bre.12146.

Zimmermann G, Blöcher G, Reinicke A, Brandt W. Rock specific hydraulic fracturing and matrix acidizing to enhance a geothermal system—concepts and field results. Tectonophysics. 2011;503(1-2):146-54. https://doi.org/10.1016/j. tecto.2010.09.026

\section{Publisher's Note}

Springer Nature remains neutral with regard to jurisdictional claims in published maps and institutional affiliations.

\section{Submit your manuscript to a SpringerOpen ${ }^{\odot}$ journal and benefit from:}

- Convenient online submission

Rigorous peer review

Open access: articles freely available online

- High visibility within the field

- Retaining the copyright to your article

Submit your next manuscript at $\boldsymbol{\Delta}$ springeropen.com 